\title{
Investigation of Burnout Levels of Physical Education and Sports Teachers during Covid-19 Period
}

\author{
Berna Karakoç (Corresponding author) \\ School of Physical Education and Sport, Department of Physical Education and Sport \\ Kilis 7 Aralık University, Mehmet Sanlı Mah. Doğan Güreş Paşa Bul. No:134, Kilis, Turkey \\ Tel: 90-348-814-2666 E-mail: bernakara27@hotmail.com
}

\section{Önder Karakoç}

School of Physical Education and Sport, Department of Physical Education and Sport Kilis 7 Aralık University, Mehmet Sanlı Mah. Doğan Güreş Paşa Bul. No:134, Kilis, Turkey Tel: 90-348-814-2666 E-mail: onderkarakoc@kilis.edu.tr

\section{Özgür Aktaş}

School of Physical Education and Sport, Department of Physical Education and Sport Kilis 7 Aralık University, Mehmet Sanlı Mah. Doğan Güreş Paşa Bul. No:134, Kilis, Turkey Tel: 90-348-814-2666 E-mail: ozguraktas@kilis.edu.tr

\section{Murat Arslan}

School of Physical Education and Sport, Department of Physical Education and Sport Kilis 7 Aralık University, Mehmet Sanlı Mah. Doğan Güreş Paşa Bul. No:134, Kilis, Turkey Tel: 90-348-814-2666_E-mail: murat.arslan1393@gmail.com

Received: June 28, $2021 \quad$ Accepted: September 11, 2021

Published: September 29, 2021

doi:10.5296/jei.v7i2.18963 URL: https://doi.org/10.5296/jei.v7i2.18963 


\section{Abstract}

Due to the COVID-19 pandemic, it was decided to conduct educational activities online and the burnout status of teachers who suddenly switched to distance education became a matter of curiosity. This study was carried out to examine the burnout levels of physical education and sports teachers during the Covid-19 period and to examine possible changes that may occur after this process by getting information about how they will approach their profession. profession and students. In this context, the research group consists of 210 physical education and sports teachers, 142 men and 68 women. These teachers took a break from face-to-face education due to the pandemic and continued their lessons with online education. The Maslach Burnout Inventory and 3 semi-structured questions were used to find out the emotional states of physical education and sports teachers and how they approached students during and after the pandemic. IBM SPSS 22 statistical program was used in the analysis of the data obtained from the scale. Analysis of normality showed that the data were normally distributed. Parametric test independent samples t-test was used to compare paired groups, one-way ANOVA was used to compare more than two groups and the level of significance was accepted as $(\mathrm{p})<.05$. In addition, the content analysis method was used in the analysis of the data obtained from the semi-structured interview form. The results showed that physical education and sports teachers participating in the study experienced moderate burnout. It was determined that the most negatively affected aspect of teachers was emotional exhaustion during the Covid-19 pandemic. There was no significant difference between the burnout levels of physical education and sports teachers according to the variables of gender, age, professional seniority, the type of sports they do. Physical education and sports teachers stated that they missed their students and they wanted face-to-face education to start at school, while more than half of the teachers stated that their attitudes to students will change after the pandemic.

Keywords: Burnout, Covid-19, Pandemic, Physical education, Stress, Teachers

\section{Introduction}

As of 2020, Covid-19 emerged in many countries of the world and various measures had to be taken all over the world to prevent the spread of the epidemic. One of the most striking of these measures was the closure of schools as restrictive measures, which affected 1.2 billion students worldwide (UNESCO, 2020). Thus, 2020 Covid-19 pandemic has shown an immediate requirement for a global and unplanned change in school education. When schools were closed all around the world to protect educators' and children's health, a large number of educators rapidly turned to distance education, which includes technology.

Researchers in education have repeatedly emphasized how important teachers are as frontline workers in education reform (Kin \& Kareem, 2016). During this process, it was suggested that teachers had to work for a successful education, while planned behavior models and attitudes of teachers had to be considered to understand teachers' behaviors about Covid-19 (Ajzen, 2015). It is thought that one of the most important changes pandemic caused in educational practices is the transition to online education. In particular, teachers needed to adapt pedagogic practices to their courses to maintain a pedagogical connection with their 
students (Al-Fudail \& Mellar, 2008; Crawford et al., 2020). With the sudden cancellation of face-to-face education in classrooms, teachers had to re-explore themselves to be experts in video and online education without forgetting about pedagogic quality. They needed to improve their knowledge and renew themselves with new teaching models. During this pandemic process, teachers experienced uncertainties about using technology as the main method and transition to online education; while some believe this to be the reasonable thing to do in terms of both learning and safety, others believe that online classes emphasize inequalities (Sokal et al., 2020). As a result of this, the necessity of making use of technology as primary teaching method emerged as a worrying situation and the term "techno stress" began to be used to explain how teachers who had to use technology in their teaching felt (Diehl \& Marin, 2016).

These situations which may have a negative effect on teachers may cause a feeling of burnout, intense negative situations such as distress, alienation, anxiety, loss of motivation and situations such as emotional burnout, coldness, indifference. These may cause a social situation in teachers which initially occurs with weakness, loss of value, violence and indiscipline and leads to an identity crisis and questioning of professional preferences.

This situation, which is called burnout syndrome, is unfortunately very common in teaching profession. It may cause suffering due to being exposed to very stressful situations all the time, physical or emotional burnout (Souza \& Leite, 2011). According to World Health Organization, the symptoms of burnout are as follows:

- $\quad$ Sleep disorders

- Anxiety

- Depression

- Irritability

- $\quad$ Physical fatigue

- Headache

- $\quad$ Muscle tension

- Gastrointestinal changes

During the pandemic, the difficulties experienced in terms of education, online teaching and emotional difficulties meant a new challenge for teachers of physical education and sports. Since physical education has a very important place for both physical and mental health, being deprived of physical activities affected both teachers and students very much (Cheval et al., 2020). Teachers of physical education and sports have important responsibilities such as raising healthy individuals. They have duties such as reducing the risk for obesity, training athletes for infrastructures of sports clubs, discovering and training athletes to represent the country and to meet children's needs to move and play games. Teachers of physical education and sports should first learn the skills they will teach in practice and they should actively participate in them so that they can teach both theoretically and practically (Filiz, 2004). In 
physical education and sports, teacher-student interaction is extremely important. Information can easily be transferred during face-to-face education. During the pandemic, education was insufficient not only in terms of learning information but also in terms of practicing what is learned. Subject should be presented effectively and practices should be made in correct communication with students (Gökçe, 2004). However, it is true that different conditions affect the quality of education. However, during this process, classes were taught with online education. Although teachers tried to teach their classes despite everything, there have been setbacks in practical classes of physical education and sports teachers. Therefore, this study was conducted to examine the states of physical education and sports teachers in terms of the effects of pandemic on teachers' stress and burnout and to research how their attitudes towards their profession and students will be after the pandemic.

\section{Method}

This part of the study will give information about the research model, research group, data collection tools used in the research and data analysis.

\subsection{Research Model}

In this study, mixed models were used to find out the burnout levels of non-actively working (non-face to face) physical education and sports teachers during COVID-19 pandemic period. Mixed methods are model which is commonly used in the fields of health, social and behavioural sciences. In this model, researchers collect qualitative and quantitative data with the aim of understanding the research problem, integrates both data sets and thus reaches conclusions (Creswell, 2017).

In this study, parallel mixed methods, which is one of the mixed methods designs, were used. Parallel mixed method aims to collect both quantitative and qualitative data simultaneously, to integrate these two types of data and to make use of results in understanding a research problem (Firat, Yurdakul, \& Ersoy, 2014).

\subsection{Participants}

Convenience sampling (random) method was used in this study. There isn't a detailed study in random sample selection. For this reason, we cannot talk about a systematic sampling process. In general the researcher's preferences determine the sample size (Baştürk \& Taştepe, 2013). The research group of this study includes 210 physical education and sports teachers, $142(67.6 \%)$ males and $68(32.4 \%)$ females. These teachers had suspended face-to-face education due to pandemic and they were continuing their classes through online education.

\subsection{Data Collection Tools}

\subsubsection{Personal Information Form}

In the study, sociodemographic characteristics of physical education and sports teachers such as gender, age, professional seniority and branch were identified by a personal information form prepared by the researchers.

\subsubsection{Maslach Burnout Inventory}


Maslach Burnout Inventory, which was developed by (Maslach \& Jackson, 1981) and adapted into Turkish by Ergin (1992) was used as data collection instrument. The inventory consists of three subscales as emotional exhaustion, depersonalization and personal accomplishment. The inventory is a 5-Likert type scale and the questions in emotional exhaustion subscale are scored as 1 "Never"; 2 "Rarely"; 3 "Sometimes"; 4 "Usually" and 5 "Always", while the questions in the personal accomplishment subscale are scored and evaluated the opposite way. Cronbach alpha $(\alpha)$ values of subscales and overall scale were (.784) for emotional exhaustion subscale, (.878) for depersonalization subscale, (.783) for personal accomplishment subscale and (.890) for overall scale. All the values were close to 1 (Tavakol \& Dennick, 2011), which can be interpreted as the scale's being reliable.

\subsubsection{Semi-Structured Interview Form}

The attitudes of physical education and sports teachers towards their professions and students during and after the pandemic period were determined with an interview form including 3 open-ended questions. Initially, the form included 4 questions, later it was edited in line with the views of field experts to include 3 questions and it was found to support Maslach Burnout Inventory partly. The form included the following questions:

(1) Since I cannot perform my profession face-to-face due to COVID-19 pandemic, I feel ...

(2) When the COVID-19 pandemic ends, while performing my profession, I will feel ...

(3) Before the COVID-19 pandemic, my attitude to students was ..., after the pandemic, it will be ...

\subsection{Data Collection and Analysis}

Data collection instruments were first transferred to online platform, and then they were sent to teachers through electronic medium. Participants were informed that participation was on a voluntary basis. The data obtained were analyzed through IBM SPSS 22 package program. Normality analysis showed that the data had a normal distribution. For paired comparisons, parametric test independent samples $t$ test was used, while the comparison of more than two groups was carried out with one way Anova. $(\mathrm{p})<.05$ was considered as statistically significant. Content analysis method was used to analyze the answers to qualitative questions, which were grouped under titles in line with literature review and shown in tables. In content analysis, first data is coded, then the themes are determined, next the data is organized according to themes-codes and lastly the findings are interpreted.

The coding of qualitative data set was made according to the branch, age range, gender and sequence number given by the researchers:

Professional seniority; 1-5 years (1), 6-10 years (2), 11-15 years (3), 16 years and over (4)

Branch; Individual sports (1), team sports (2),

Age range 22-25 years (1), 26-29 years (2), 30-35 years (3), 34-37 years (4), 38+ (5).

Example: Imagine that a 25-year-old female participant with a professional seniority of 6-10 years who was engaged in team sports was the $9^{\text {th }}$ participant in the study. The coding was made as 2,2,1,F,9. Qualitative data were analyzed with content analysis method. A total of 
630 codes were obtained from the answers to the 3 open-ended questions. In terms of reliability, the consensus between the three researchers was calculated with "consensus" or "disagreement" as recommended by Miles, Huberman and Saldana (1994) and 96\% consensus between the researchers.

$$
\text { Reliability }=\text { Consensus } /(\text { Consensus }+ \text { Disagreement }) 610 /(610+20)=.96
$$

Table 1. Results of normality test of data

\begin{tabular}{|l|l|l|}
\hline & Skewness & Kurtosis \\
\hline Emotional exhaustion & 1.127 & 1.492 \\
\hline Depersonalization & 1.313 & -1.070 \\
\hline Personal accomplishment & 1.006 & 1.226 \\
\hline Total burnout & 1.416 & .933 \\
\hline
\end{tabular}

In Table 1, it was determined that the total of the scale and its sub-dimensions do show a normal distribution since the skewness and kurtosis values are between -1.5 and +1.5 (Tabachnick \& Fidell, 2013). For this reason, parametric tests were preferred in this study. 


\section{Results}

Table 2. Demographic characteristics of teachers of physical education and sports

\begin{tabular}{|c|c|c|c|}
\hline & & $\mathrm{n}$ & $\%$ \\
\hline \multirow{2}{*}{ Gender } & Male & 142 & 67.6 \\
\hline & Female & 68 & 32.4 \\
\hline \multirow{5}{*}{ Age } & $22-25$ & 39 & 18.6 \\
\hline & $26-29$ & 52 & 24.8 \\
\hline & $30-33$ & 27 & 12.9 \\
\hline & $34-37$ & 15 & 7.1 \\
\hline & $38+$ & 77 & 36.7 \\
\hline \multirow{4}{*}{ Professional seniority } & $1-5$ & 101 & 48.1 \\
\hline & $6-10$ & 36 & 17.1 \\
\hline & $11-15$ & 11 & 5.2 \\
\hline & $16+$ & 62 & 29.5 \\
\hline \multirow{2}{*}{ Type of sport } & Individual sports & 65 & 31.0 \\
\hline & Team sports & 145 & 69.0 \\
\hline \multirow{7}{*}{ Geographical region } & Marmara & 9 & 4.3 \\
\hline & Aegean & 11 & 5.2 \\
\hline & Mediterranean & 24 & 11.4 \\
\hline & Central Anatolia & 27 & 12.9 \\
\hline & Black Sea & 31 & 14.8 \\
\hline & South-eastern Anatolia & 80 & 31.8 \\
\hline & Eastern Anatolia & 28 & 13.3 \\
\hline
\end{tabular}

When Table 2 is examined, it can be seen that a total of 210 physical education and sports teachers participated in the study. $142(67.6 \%)$ of these were male, while $68(32.4 \%)$ were female. Of the physical education and sports teachers, 39 (18.6\%) were between 22 and 25 years of age, $52(24.8 \%)$ were between 26 and 29 years of age, $27(12.9 \%)$ were between 30 and 33 years of age, 15 (7.1\%) were between 34 and 37 years of age, and $77(36.7 \%)$ were 38 years of age and older. In terms of professional seniority, it was found that $101(48.1 \%)$ had 1-5 years, $36(17.1 \%)$ had 6-10 years, $11(5.2 \%)$ had $11-15$ years and $62(29.5 \%) 16$ years and longer professional seniority. While $65(31 \%)$ were interested in individual sports, 145 
$(69 \%)$ were interested in team sports. The data in the study were collected from physical education and sports teachers living in different regions of Turkey. According to the results, 9 (4.3\%) were living in Marmara region, 11 (5.2\%) in Aegean region, $24(11.4 \%)$ in Mediterranean region, 27 (12.9\%) in Central Anatolia region, 31 (14.8\%) in Black Sea region, 80 (31.8\%) in South-eastern Anatolia region and 28 (13.3\%) were living in Eastern Anatolia region.

Table 3. Descriptive characteristics of physical education and sports teachers in terms of burnout inventory

\begin{tabular}{|l|l|l|l|l|l|}
\hline Scale & $\mathrm{n}$ & Min. & Max. & $\overline{\mathrm{x}}$ & Std. Dev. \\
\hline Emotional exhaustion & 210 & 1.00 & 4.56 & 2.31 & .848 \\
\hline Depersonalization & 210 & 1.00 & 5.00 & 1.95 & .809 \\
\hline Personal accomplishment & 210 & 1.00 & 4.75 & 2.29 & .690 \\
\hline Total burnout & 210 & 1.00 & 4.41 & 2.22 & .632 \\
\hline
\end{tabular}

When Table 3 is examined, it can be seen that physical education and sports teachers had moderate total burnout levels $(\overline{\mathrm{x}}=2.22)$ and the aspect that was most negatively affected during the pandemic period was emotional exhaustion $(\overline{\mathrm{x}}=2.31)$ subscale.

Table 4. Comparison of burnout states of the teachers in terms of gender

\begin{tabular}{|c|c|c|c|c|c|c|}
\hline Scale total and subscales & Gender & $\mathrm{n}$ & $\overline{\mathrm{x}}$ & Std. Dev. & $\mathrm{t}$ & $\mathrm{p}$ \\
\hline \multirow{2}{*}{ Emotional exhaustion } & Male & 142 & 2.24 & .822 & \multirow{2}{*}{-1.666} & \multirow{2}{*}{.097} \\
\hline & Female & 68 & 2.45 & .885 & & \\
\hline \multirow{2}{*}{ Depersonalization } & Male & 142 & 1.91 & .761 & \multirow{2}{*}{-1.028} & \multirow{2}{*}{.305} \\
\hline & Female & 68 & 2.03 & .890 & & \\
\hline \multirow{2}{*}{ Personal accomplishment } & Male & 142 & 2.29 & .643 & \multirow{2}{*}{-.162} & \multirow{2}{*}{.871} \\
\hline & Female & 68 & 2.30 & .788 & & \\
\hline \multirow{2}{*}{ Total burnout } & Male & 142 & 2.18 & .602 & \multirow{2}{*}{-1.276} & \multirow{2}{*}{.204} \\
\hline & Female & 68 & 2.30 & .671 & & \\
\hline
\end{tabular}

When Table 4 is examined, it can be seen that as a result of the independent samples test conducted, burnout inventory and subscales (emotional exhaustion, depersonalization and personal accomplishment) mean scores of physical education and sports teachers did not differ significantly in terms of gender. 
Table 5. Comparison of burnout states of the teachers in terms of branch

\begin{tabular}{|c|c|c|c|c|c|c|}
\hline Scale total and subscales & Branch & $\mathrm{n}$ & $\overline{\mathrm{x}}$ & Std. Dev. & $\mathrm{t}$ & $\mathrm{p}$ \\
\hline \multirow{2}{*}{ Emotional exhaustion } & Individual & 65 & 2.23 & .864 & \multirow{2}{*}{-.852} & \multirow{2}{*}{.395} \\
\hline & Team & 145 & 2.34 & .840 & & \\
\hline \multirow{2}{*}{ Depersonalization } & Individual & 65 & 1.80 & .801 & \multirow{2}{*}{-1.796} & \multirow{2}{*}{.074} \\
\hline & Team & 145 & 2.02 & .803 & & \\
\hline \multirow{2}{*}{ Personal accomplishment } & Individual & 65 & 2.18 & .622 & \multirow{2}{*}{-1.594} & \multirow{2}{*}{.113} \\
\hline & Team & 145 & 2.34 & .711 & & \\
\hline \multirow{2}{*}{ Total burnout } & Individual & 65 & 2.12 & .605 & \multirow{2}{*}{-1.623} & \multirow{2}{*}{.106} \\
\hline & Team & 145 & 2.37 & .641 & & \\
\hline
\end{tabular}

When Table 5. is examined, it can be seen that as a result of the independent samples t test conducted, burnout inventory and subscales (emotional exhaustion, depersonalization and personal accomplishment) mean scores of physical education and sports teachers did not differ significantly in terms of the variable of branch. 
Table 6. Comparison of burnout states of the teachers in terms of age

\begin{tabular}{|c|c|c|c|c|c|c|}
\hline Scale total and subscales & Age Group & $\mathrm{n}$ & $\bar{x}$ & Std. Dev. & $\mathrm{F}$ & $\mathrm{p}$ \\
\hline \multirow{5}{*}{ Emotional exhaustion } & $22-25$ & 39 & 2.11 & .842 & \multirow{5}{*}{1.795} & \multirow{5}{*}{.131} \\
\hline & $26-29$ & 52 & 2.29 & .908 & & \\
\hline & $30-33$ & 27 & 2.10 & .691 & & \\
\hline & $34-37$ & 15 & 2.57 & 1.01 & & \\
\hline & $38+$ & 77 & 2.44 & 0.80 & & \\
\hline \multirow{5}{*}{ Depersonalization } & $22-25$ & 39 & 2.08 & .885 & \multirow{5}{*}{.706} & \multirow{5}{*}{.589} \\
\hline & $26-29$ & 52 & 1.97 & .863 & & \\
\hline & $30-33$ & 27 & 2.02 & .841 & & \\
\hline & $34-37$ & 15 & 2.01 & .822 & & \\
\hline & $38+$ & 77 & 1.84 & .711 & & \\
\hline \multirow{5}{*}{ Personal accomplishment } & $22-25$ & 39 & 2.23 & .645 & \multirow{5}{*}{.635} & \multirow{5}{*}{.638} \\
\hline & $26-29$ & 52 & 2.39 & .723 & & \\
\hline & $30-33$ & 27 & 2.16 & .576 & & \\
\hline & $34-37$ & 15 & 2.36 & .567 & & \\
\hline & $38+$ & 77 & 2.29 & .741 & & \\
\hline \multirow{5}{*}{ Total burnout } & $22-25$ & 39 & 2.15 & .613 & \multirow{5}{*}{.627} & \multirow{5}{*}{.644} \\
\hline & $26-29$ & 52 & 2.25 & .701 & & \\
\hline & $30-33$ & 27 & 2.10 & .596 & & \\
\hline & $34-37$ & 15 & 2.36 & .713 & & \\
\hline & $38+$ & 77 & 2.25 & .599 & & \\
\hline
\end{tabular}

When Table 6 is examined, it can be seen that as a result of the one-way analysis of variance (Anova) conducted, burnout inventory and subscales (emotional exhaustion, depersonalization and personal accomplishment) mean scores of physical education and sports teachers did not differ significantly in terms of the variable of age. 


\section{Macrothink}

Table 7. Comparison of burnout states of the teachers in terms of professional seniority

\begin{tabular}{|c|c|c|c|c|c|c|}
\hline Scale total and subscales & Professional seniority & $\mathrm{n}$ & $\overline{\mathrm{x}}$ & Std. Dev. & $\mathrm{F}$ & $\mathrm{p}$ \\
\hline \multirow{4}{*}{ Emotional exhaustion } & $1-5$ years & 101 & 2.24 & .841 & \multirow{4}{*}{2.880} & \multirow{4}{*}{0.37} \\
\hline & $6-10$ years & 36 & 2.20 & .882 & & \\
\hline & $11-15$ years & 11 & 1.92 & .695 & & \\
\hline & 16 years + & 62 & 2.55 & .823 & & \\
\hline \multirow{4}{*}{ Depersonalization } & $1-5$ years & 101 & 2.10 & .870 & \multirow{4}{*}{2.207} & \multirow{4}{*}{0.88} \\
\hline & $6-10$ years & 36 & 1.77 & .756 & & \\
\hline & $11-15$ years & 11 & 1.87 & .596 & & \\
\hline & 16 years + & 62 & 1.83 & .738 & & \\
\hline \multirow{4}{*}{ Personal accomplishment } & $1-5$ years & 101 & 2.32 & .613 & \multirow{4}{*}{.187} & \multirow{4}{*}{.906} \\
\hline & $6-10$ years & 36 & 2.23 & .773 & & \\
\hline & $11-15$ years & 11 & 2.36 & .651 & & \\
\hline & 16 years + & 62 & 2,28 & .772 & & \\
\hline \multirow{4}{*}{ Total burnout } & $1-5$ years & 101 & 2.24 & .618 & \multirow{4}{*}{.807} & \multirow{4}{*}{.491} \\
\hline & $6-10$ years & 36 & 2.11 & .759 & & \\
\hline & $11-15$ years & 11 & 2.07 & .521 & & \\
\hline & 16 years + & 62 & 2.29 & .617 & & \\
\hline
\end{tabular}

When Table 7 is examined, it can be seen that as a result of the one-way analysis of variance (Anova) conducted, burnout inventory and subscales (emotional exhaustion, depersonalization and personal accomplishment) mean scores of physical education and sports teachers did not differ significantly in terms of professional seniority. 


\section{Macrothink}

Table 8. Teacher's opinions (during the pandemic)

\begin{tabular}{|l|l|l|l|}
\hline Theme & Sub Theme & Codes & $\mathrm{f}$ \\
\hline \multirow{5}{*}{ Mental or Physical Condition } & \multirow{5}{*}{ Negative Mental or Physical Condition } & Unhappy & \multicolumn{1}{l}{47} \\
\cline { 3 - 4 } & & Sad & 34 \\
\cline { 3 - 4 } & & Insufficient & 25 \\
\cline { 3 - 4 } & & Exhausted & 23 \\
\cline { 3 - 4 } & Helpless & 21 \\
\cline { 3 - 4 } & \multirow{3}{*}{ Positive Mental or Physical Condition } & Introvert & 19 \\
\cline { 3 - 4 } & & Refreshed & 17 \\
\cline { 3 - 4 } & & Improved & 24 \\
\hline
\end{tabular}

In Table 8, the answers of physical education and sports teachers who could not perform their profession during quarantine days to the question "Since I cannot perform my profession face-to-face due to COVID-19 pandemic, I feel ..." were analyzed with content analysis method.

Some of the teachers' answers are given below:

3,1,4,F,11 "I feel helpless because I don't know what to do."

3,1,4,M,18 "I feel sad because I was away from my students."

2,2,3,F,42 "I feel physically and mentally exhausted."

1,2,2,M,5 "I feel insufficient because I haven't been able to work well with my students for a long time."

These answers can generally be expressed as "negative situations due to pandemic-induced quarantine practices".

4,2,5,F,66 "I feel refreshed because I had the opportunity to rest for a long time."

4,1,5,M,21 "I feel improved because I had the opportunity to read a lot of books."

These answers can generally be expressed as "positive situations due to pandemic-induced quarantine practices". 


\section{Al Macrothink}

Table 9. Teacher's opinions (post pandemic)

\begin{tabular}{|l|l|l|l|}
\hline Theme & Sub Theme & Codes & $\mathrm{f}$ \\
\hline \multirow{5}{*}{ Mental or Physical Condition } & \multirow{5}{*}{ Positive Mental or Physical Condition } & Energized & 51 \\
\cline { 3 - 4 } & & Excited & 33 \\
\cline { 3 - 4 } & & Longing & 21 \\
\cline { 3 - 4 } & \multirow{5}{*}{ Negative Mental or Physical Condition } & Development & 18 \\
\cline { 3 - 4 } & & Motivated & 17 \\
\cline { 3 - 4 } & Happy & 15 \\
\cline { 3 - 4 } & & Exhausted & 14 \\
\cline { 3 - 4 } & Disadvantaged & 11 \\
\cline { 3 - 4 } & Alienated & 25 \\
\hline
\end{tabular}

In table 9., the answers of physical education and sports teachers who could not perform their profession during quarantine days to the question "When the COVID-19 pandemic ends, while performing my profession, I will feel ..." were analyzed with content analysis method.

Some of the teachers' answers are given below:

1,1,2,F,36 "I will feel energized because I rested a lot."

2,1,3,M,71 “I will feel longing because I miss the students and school so much."

1,2,2,F,20 "I will feel excited."

2,2,3,M,57 "I will feel motivated because I find face-to-face training more beneficial.".

2,2,3,F,33 "I will feel alienated because I have almost forgotten most things."

3,1,4,M,26 "I will feel exhausted because this process has affected me very negatively."

3,1,4,F,48 "I will feel disadvantaged because I could not improve myself because of the process."

2,1,3,M,79 "I will feel insufficient because I could not improve myself because of the process." 


\section{MlMacrothink}

Table. 10 Teacher's opinions

\begin{tabular}{|l|l|l|l|}
\hline \multirow{4}{*}{ Theme } & Sub Theme & Codes & $\mathrm{f}$ \\
\hline \multirow{4}{*}{ Approach } & \multirow{4}{*}{ Stabil Approach } & Careful & 34 \\
\cline { 3 - 4 } & Moderate & 24 \\
\cline { 3 - 4 } & Sincere & 15 \\
\cline { 3 - 4 } & & Caring & 11 \\
\cline { 3 - 4 } & \multirow{3}{*}{ Changing Approach } & Thoughtful & 9 \\
\cline { 3 - 4 } & & More understanding & 44 \\
\cline { 3 - 4 } & More supportive & 32 \\
\cline { 3 - 4 } & More motivating & 22 \\
\cline { 3 - 4 } & & More solution oriented & 19 \\
\hline
\end{tabular}

In table 10., the answers of physical education and sports teachers who could not perform their profession during quarantine days to the question "Before the COVID-19 pandemic, my attitude to students was ..., after the pandemic, it will be ..." were analyzed with content analysis method. While more than half of the teachers stated that there would be a change in their behaviors, some teachers stated that they would not make any changes in their behaviors after the pandemic process.

Some of the teachers' answers are given below.

3,1,4,M,93 "I was careful before the pandemic and I will continue to be careful after the pandemic."

1,1,2,F,101 "I was thougtful before the pandemic and I will continue to be thougtful after the pandemic."

Such answers can be grouped under the heading "Statements indicating that the approaches will be the same".

2,1,3,M,28 "I was understanding before the pandemic, but I will continue to be even more understanding after the pandemic because we had bad times."

2,1,3,F,125 "I was solution oriented before the pandemic, but I will continue to be even more solution oriented after the pandemic because students need this."

Such answers can be grouped under the heading "Statements indicating that the approaches will be the different".

\section{Discussion}

Covid-19, which has had a lot of negative effects in the world, has also negatively affected areas such as health, education and economy. In terms of education, teachers of physical education and sports had to be away from applied courses. They tried to meet their students' needs and teach their lessons with online education. This study aims to find out their 
professional burnout perceptions during the pandemic process and to contribute to literature about how their approaches to their students and professions will be after the pandemic.

Although a great majority of physical education and sports teachers who were away from their students during practices due to Covid-19 pandemic experienced negative emotional states (Table 8) in the pandemic, their burnout scores (Table 2) show that they were able to cope with this negative process. It is also thought that the reasons for this is the presence of physical education and sports teachers who were able to rest and spare more time to their loved ones by considering the pandemic as an opportunity (Table 8). In the evaluation of burnout states of physical education and sport teachers, negative situations due to quarantine practices implemented in the pandemic were very high. However, they stated that in the period after the pandemic, they will have positive attitudes such as "energetic, eager as if starting the profession again, excited and full of longing" (Table 9). It is thought that this situation develops mental toughness and prevents having burnout. In addition, most of the physical education and sports teachers stated that in the pre-pandemic process, they had the chance to review their approaches towards students, they decided to change these approaches and had the opportunity to develop themselves in a positive way.

Teachers of physical education and sports are generally teachers who have sports past. It is known that sport has positive effects on mental toughness. In Y1ldiz's (2017) study, sport was found to have effects on mental toughness in athletes. It can be thought that getting engaged in a sport branch makes physical education and sports teachers more resistant to difficult life conditions. However, it is thought that their struggle gets stronger with fast decision making and adaptation to difficult conditions.

In a study conducted on teachers in Australia, (Ainley \& Carstens, 2018) found that about one fourth of teachers $(24 \%)$ stated that their job had a more or less negative influence on their mental health and $21 \%$ reported that their job had a more or less negative influence on their physical health. It was found that if their perceived stress level was high, they resorted to emotion regulation strategies intensively (Ainley \& Carstens, 2018).

In another study, personal consequences of stress were found to be far-reaching for teachers. It was reported that they might increase burnout, physical and emotional distress, decrease self-confidence and self-respect and damage personal relationships (Gardner, 2010).

Horzum (2003) concluded that courses other than practical and vocational courses can be given through online education. Physical education and sport is a course in which techniques and moves specific to lesson are taught and most of the time corrected through feedback. In addition, it is a course which provides the opportunity to move freely with different equipment in an environment other than the classroom (Blakemore et al., 1992). In this case, it is thought that being stressful causes physical education and sports teachers to have increased burnout. Stress may sometimes cause teachers to quit their job and this may cause them to lose their experience and skills to a great extent (Howard \& Johnson, 2004).

In their study, Riley et al. stated that emotional demands, demands to hide emotions and work-family conflicts had much higher effect size. They also stated that burnout, sleep 
problems and stress had very large effect size (Riley et al., 2020).

Some studies mention the following factors as the effects of teacher well-being on students' learning and factors that are useful for stress and burnout:

- $\quad$ Sources to increase the feeling of self-sufficiency;

- Connecting with students and colleagues;

- $\quad$ Support from colleagues;

- $\quad$ Appreciation for what they do (Klassen et al., 2012; Flook et al., 2013; Gardner 2010; Schwarzer \& Hallum, 2008).

In their study, Schwarzer and Hallum (2008) mentioned that teachers had to take pleasure from their work for high level of energy and to dedicate themselves to teaching. They concluded that for teachers, daily influences of having to deal with low quality teacher-student relationships could cause lower participation and pleasure levels and higher levels of anxiety, rage and emotional exhaustion. While the occupation of teachers is positively associated with personal coping sources, it is negatively associated with burnout. In another study conducted to evaluate the effects of stress and burnout on teaching efficacy, Flook et al. (2013) stated that creating classroom environment played a central role. The result of this study that physical education and sports teachers will be more efficient and have less burnout in face-to-ace education is in parallel with the results of our study.

As a conclusion, the teachers in the study were found to have low burnout levels and the most affected aspect during the pandemic period was found as emotional exhaustion. There were no statistically significant differences between the burnout perceptions of physical education and sports teachers in terms of gender, age, professional seniority, sport branch they were engaged in and geographical region they lived in. Physical education and sports teachers stated that they missed their students during the COVID-19 pandemic and wanted face-to-face education to start in school and a great majority of the teachers stated that their attitudes towards students would be different after the pandemic.

The present study conducted for teachers of physical education and sports can be applied to all teachers and other profession groups.

It is recommended to get help from experts to increase mental toughness methods and use coping methods to prevent negative situations that occur with COVID-19 process.

\section{References}

Ainley, J., \& Carstens, R. (2018). Teaching and learning international survey (TALIS) 2018: Conceptual framework. OECD Publishing.

Ajzen, I. (2015). The theory of planned behaviour is alive and well, and not ready to retire: A commentary on Sniehotta, Presseau, and Araújo-Soares. Health Psychology Review, 9(2), 131-137. https://doi.org/10.1080/17437199.2014.883474

Al-Fudail, M., \& Mellar, H. (2008). Investigating teacher stress when using technology. 
Computers \& Education, 51(3), 1103-1110. https://doi.org/10.1016/j.compedu.2007.11.004

Baştürk, S., \& Taştepe, M. (2013). Evren ve örneklem. Bilimsel araştırma yöntemleri. Ankara, Vize Yayınc1lık.

Blakemore, C. L., Hilton, H. G., Harrison, J. M., Pellett, T. L., \& Gresh, J. (1992). Comparison of students taught basketball skills using mastery and nonmastery learning methods. Journal of Teaching in Physical Education, 11(3), 235-247. https://doi.org/10.1123/ jtpe.11.3.235

Cheval, B., Sivaramakrishnan, H., Maltagliati, S., Fessler, L., Forestier, C., Sarrazin, P., ... Boisgontier, M. P. (2021). Relationships between changes in self-reported physical activity, sedentary behaviour and health during the coronavirus (COVID-19) pandemic in France and Switzerland. Journal of Sports Sciences, 39(6), 699-704. https://doi.org/10.1080/02640414. 2020.1841396

Crawford, J., Butler-Henderson, K., Rudolph, J., Malkawi, B., Glowatz, M., Burton, R., ... Lam, S. (2020). COVID-19: 20 countries' higher education intra-period digital pedagogy responses. Journal of Applied Learning \& Teaching, 3(1), 1-20. https://doi.org/10.37074/ jalt.2020.3.1.7

Creswell, J. W. (2017). In M. Sözbilir (Ed.), A concise introduction to mixed methods research. Ankara, Pegem.

Diehl, L., \& Marin, A. H. (2016). Adoecimento mental em professores brasileiros: Revisão sistemática da literatura. Estudos Interdisciplinares em Psicologia, 7(2), 64-85. https://doi.org/10.5433/2236-6407.2016v7n2p64

Ergin, C. (1992). Doktor ve hemşirelerde tükenmislik ve Maslach tükenmislik ölceginin uyarlanması. VII Ulusal Psikoloji Kongresi, September 22, 1992, Ankara, Turkey.

Fırat, M., Yurdakul, I. K., \& Ersoy, A. (2014). Bir eğitim teknolojisi araştırmasına dayalı olarak karma yöntem araştırması deneyimi. Eğitimde Nitel Araştırmalar Dergisi, 2(1), 64-85. https://doi.org/10.14689/issn.2148-2624.1.2s3m

Filiz, K. (2004). Gazi Üniversitesi beden eğitimi ve spor yüksekokulunda okuyan öğrencilerin meslekle ilgili okuma ve araştırma alışkanlıkları. Gazi Üniversitesi Gazi Ĕ̆itim Fakültesi Dergisi, 24(2).

Flook, L., Goldberg, S. B., Pinger, L., Bonus, K., \& Davidson, R. J. (2013). Mindfulness for teachers: A pilot study to assess effects on stress, burnout and teaching efficacy. Mind, Brain and Education: The Official Journal of the International Mind, Brain, and Education Society, 7(3), 182-195. https://doi.org/10.1111/mbe.12026

Gardner, R. C. (2010). Motivation and second language acquisition: The socio-educational model (Vol. 10). Peter Lang.

Gökçe E. (2004). Student and teacher views on active learning process in primary education. Akdeniz Journal of Educational, 1, 53-64. 


\section{Macrothink}

Journal of Educational Issues

ISSN 2377-2263

2021, Vol. 7, No. 2

Horzum, M. B. (2003). Öğretim elemanlarının internet destekli ĕgitime yönelik düşünceleri:

Sakarya Üniversitesi örneği (Master's thesis, Sakarya University, Turkey).

Howard, S., \& Johnson, B. (2004). Resilient teachers: Resisting stress and burnout. Social Psychology of Education, 7(4), 399-420. https://doi.org/10.1007/s11218-004-0975-0

Kareem, O., \& Kin, T. M. (2018). Attitudes toward Change: A Comparison Between Senior Assistants and Teachers in Malaysian Secondary Schools. The International Journal of Academic Research in Business and Social Sciences, 8, 249-265. http://doi.org/10.6007/ IJARBSS/v8-i1/3806

Klassen, R., Perry, N., \& Frenzel, A. (2012). Teachers' relatedness with students: An underemphasized component of teachers' basic psychological needs. Journal of Educational Psychology, 104, 150-165. https://doi.org/10.1037/a0026253

Maslach, C., \& Jackson, S. E. (1981). The measurement of experienced burnout. Journal of Occupational Behavior, 2, 99-113. https://doi.org/10.1002/job.4030020205

Miles, M. B., Huberman, M. A., \& Saldana, J. (1994). Qualitative data analysis: An Expanded Sourcebook. Thousand Oaks, CA: Sage.

Riley, T. D., Curry, W., Beck, M., Berg, A., \& Ruffin, M. (2020). Feasibility of Nonanonymous Burnout Surveys in a Large Academic Department. Family medicine, 52(4), 278-28. https://doi.org/10.22454/FamMed.2020.471855

Schwarzer, R., \& Hallum, S. (2008). Perceived Teacher Self-Efficacy as a Predictor of Job Stress and Burnout: Mediation Analyses. Applied Psychology, 57, 152-171. https://doi.org/ 10.1111/j.1464-0597.2008.00359.x

Sokal, L. J., Eblie Trudel, L. G., \& Babb, J. C. (2020). Supporting teachers in times of change: The job demands- resources model and teacher burnout during the COVID-19 pandemic. International Journal of Contemporary Education, 3(2), 67-74. https://doi.org/10.11114/ ijce.v3i2.4931

Souza, A. N., \& Leite, M. P. (2011). Condições de trabalho e suas repercussões na saúde dos professores da educação básica no Brasil. Educação \& Sociedade, 32(117), 1105-1121. https://doi.org/10.1590/S0101-73302011000400012

Tavakol, M., \& Dennick, R. (2011). Making sense of Cronbach's alpha. International Journal of Medical Education, 2, 53-55. https://doi.org/10.5116/ijme.4dfb.8dfd

UNESCO. (2020). COVID-19 Educational disruption and response. Retrieved from https://en.unesco.org/covid19/educationresponse

Yıldız, M. (2017). Beden eğitimi ve spor öğretmenlerinin psikolojik şiddete (mobbing) maruz kalma ile motivasyon düzeyleri arasındaki ilişkinin incelenmesi (Unpublished master's thesis, Bartın University, Turkey). 


\section{Copyright Disclaimer}

Copyright for this article is retained by the author(s), with first publication rights granted to the journal.

This is an open-access article distributed under the terms and conditions of the Creative Commons Attribution license (http://creativecommons.org/licenses/by/3.0/). 